University of Nebraska - Lincoln

DigitalCommons@University of Nebraska - Lincoln

Sociology Department, Faculty Publications

Sociology, Department of

$12-2011$

\title{
How institutional context alters social reproduction dynamics: Ethnic track placement patterns in the U.S. and Germany
}

\author{
Regina E. Werum \\ University of Nebraska-Lincoln, rwerum2@unl.edu \\ Tomeka Davis \\ Georgia State University, soctmd@langate.gsu.edu \\ Simon Cheng \\ University of Connecticut, simon.cheng@uconn.edu
}

Follow this and additional works at: https://digitalcommons.unl.edu/sociologyfacpub

Werum, Regina E.; Davis, Tomeka; and Cheng, Simon, "How institutional context alters social reproduction dynamics: Ethnic track placement patterns in the U.S. and Germany" (2011). Sociology Department, Faculty Publications. 221.

https://digitalcommons.unl.edu/sociologyfacpub/221

This Article is brought to you for free and open access by the Sociology, Department of at DigitalCommons@University of Nebraska - Lincoln. It has been accepted for inclusion in Sociology Department, Faculty Publications by an authorized administrator of DigitalCommons@University of Nebraska - Lincoln. 


\title{
How institutional context alters social reproduction dynamics: Ethnic track placement patterns in the U.S. and Germany
}

\author{
Regina E. Werum, ${ }^{1}$ Tomeka Davis, ${ }^{2}$ and Simon Cheng ${ }^{3}$
}

\author{
1. Department of Sociology, Emory University, Atlanta, GA 30322; rwerum2@unl.edu \\ 2. Department of Sociology, Georgia State University, Atlanta, GA 30302; soctmd@langate.gsu.edu \\ 3. Department of Sociology, University of Connecticut, Storrs, CT 06269; simon.cheng@uconn.edu \\ Corresponding author - R. E. Werum
}

\begin{abstract}
How does institutional context shape the way family dynamics, especially ethnic background and parental resources, affect track placement? We contrast the track placement patterns of immigrants and ethnic majority students in two countries marked by drastic differences in the social organization of schooling. Drawing on German (GSOEP) and U.S. (NELS) data, we find that, in general, more family resources pull students from lower to higher tracks, but ethnic inequalities in these resources favor the ethnic majority groups in both countries. In addition, institutional context conditions which parental resources shape educational outcomes, and how they do so. We find that the effects of parental ties exacerbate ethnic inequalities between whites and Latinos in the U.S.; whereas in Germany, parents' community ties play a compensatory role for immigrants, who benefit from interactions with secular and ethno-religious groups. Our findings confirm previous cross-national research, but they also highlight the need to elaborate the relationship between institutional context and ethnically specific reproduction mechanisms within countries.
\end{abstract}

Keywords: Tracking, Ethnicity, Resources, Weak ties, Comparative, Germany, United States

Comparative research has long established that family resources affect educational outcomes in ways quite similar in direction but different in magnitude across countries. One of the most prominent explanations ties these mobility patterns to the social organization of schooling, especially the timing and degree of rigidity in track placement. Because track placement practices in the U.S. are relatively amorphous, it is often assumed that schools can (or should) help minimize social reproduction dynamics. In contrast, the more rigid tracking systems in existence elsewhere, which tend to be more tightly coupled to post-secondary and employment outcomes, are typically assumed to exacerbate social reproduction dynamics (also see Allmendinger, 1989;
Brunello and Checchi, 2005; Haller, 1989; Maurice et al., 1982).

We examine how institutional context moderates the way parental resources affect track placement of immigrants and ethnic majority students in two countries. Our explorative comparison focuses on the U.S. and Germany. We compare the ethnic majority with immigrants rather than indigenous minorities for two reasons. First, unlike the U.S., Germany does not have a sizeable indigenous minority group. Second, extant research on ethno-racial educational inequalities in the U.S., shows that the experience of African Americans, the largest indigenous minority, may be unique, or at the very least substantially different from that of key 
immigrant groups (Lucas and Gamoran, 2002; McNeal, 1999; Portes and MacLeod, 1996). By conducting an explicitly comparative analysis, we hope to help move the discussion beyond which system produces more stratification and towards identifying how institutional parameters may shape the very mechanisms through which the social reproduction of inequality occurs (see Powell, Werum, \& Steelman, 2004).

Many scholars have found that immigrants are more likely placed in lower tracks in Germany (Baker et al., 1985; Kristen, 2002; Seifert, 1997). The evidence for ethnic tracking patterns in the U.S. seems more mixed, with some studies suggesting that immigrants and minorities remain underrepresented in the highest tracks and others indicating that this pattern disappears (at least for blacks) when we take SES into account (Gamoran and Mare, 1989; Lucas, 1999; Lucas and Gamoran, 2002; Oakes, 1985). We also know that parental resources such as social networks or ties affect educational outcomes in both countries (Bankston, 2004; Büchel and Wagner, 2000/2001; Coleman, 1988; Jungbauer-Gans, 2004; Kao, 2004; Lareau, 2002; McNeal, 1999; Warren, 1996).

However, we know surprisingly little about how the institutional, country-specific context moderates the way specific parental resources shape ethnic track placement patterns, either in the U.S. or elsewhere (but see Ayalon and Gamoran, 2000; Jungbauer-Gans, 2004). On the one hand, the impact of parental social ties could be magnified in an institutional context marked by diffuse track placement practices, where insider knowledge is often acquired through gatekeepers or institutional agents such as teachers (e.g., Lareau, 2003; Lareau and Horvat, 1999; Stanton-Salazar and Spina, 2003). On the other hand, the impact of parental ties could be magnified in an institutional context marked by overt, rigid track placement practices that reflect the existing class structure, precisely because parental social ties are usually delimited by socio-economic status (Bourdieu, 1977; Cheng et al., 2007; DeGraaf, 1988; Kristen, 2002). Moreover, in either context, a magnified role of parental social ties might either exacerbate or mitigate existing social reproduction effects.

\section{Literature review}

\subsection{Immigration and track placement in comparative perspective}

As highly industrialized nations with a long history of mass education, Germany and the U.S. share key similarities (Ramirez \& Boli, 1987). Most importantly for our study, both countries have experienced a longstanding influx of immigrant labor. Immigration reform in both countries during the 1960s led to an unprecedented influx of immigrants from countries perceived as culturally dissimilar (European Union aspirants (Spain, Greece, Turkey); Latin America and Asia). Immigration policy in both countries deliberately pursued a "dutch door" principle (LeMay, 1987) that shaped the recruitment of adult workers with very different levels of human capital and led to group-specific selection effects. Perhaps not surprisingly, the social integration and mobility patterns experienced by these different groups diverged quickly, as reflected in public discourse about perceived "model minorities" as well as a permanent "underclass." Though the players differed (Greeks and Asians exemplifying the former; Turks and Latinos representing the latter), the evolving social stratification patterns strongly resembled each other.

In the 1980s, both countries initiated immigration reforms that sought to curtail labor recruitment and slow down the influx of economic migrants (though family unification and political asylum requests grew). Only in the 1990s and beyond did the immigration regimes of both countries begin to differ, though the resulting population changes are not reflected in the data sets we use. First, a new wave of labor migration to Germany occurred after Reunification (1990), largely from Eastern European countries. Second, beginning in the mid1990s, the U.S. began to implement stricter immigration regulations, which affected both recruitment and the naturalization process. This trend has been further accelerated by policy responses to the $9 / 11$ terrorist attacks. In contrast, German lawmakers have begun to ease regulations pertaining to the acquisition of German citizenship within the last decade.

Of all immigrant groups in Germany, Turks have constituted the largest group of (largely low-wage) "guest workers," a label that erroneously suggests their presence in Germany as temporary. In fact, by the 1990s 2nd- and even 3rd-generation immigrants were attending the public school system. Like many of the smaller immigrant groups, Turks remain under-represented in the rigorous academic track and overrepresented in intermediate and vocational tracks (Kristen, 2002). While some smaller immigrant groups are known as model minorities, Turks have noticeably higher drop-out rates and continue to cluster in low-skill occupations.

Similarly, Latinos (especially Mexicans) have long been the largest and most visible immigrant group in the U.S. Latinos remain underrepresented in academically rigorous courses and are more likely to attend formally detracked schools or report ambiguous academic records (Kao and Thompson, 2003; Lucas and 
Gamoran, 2002). Moreover, even 2nd- and 3rd-generation Latinos have one of the highest school dropout rates, experience higher teenage unemployment rates than other groups, and frequently hold low-level and unskilled occupations with little income potential (Aguirre and Martinez, 1984; Seifert, 1997; Semyonov and Herring, 2007). Thus, despite differences in modes of entry as well as cultural characteristics (e.g., religion), the two most prominent immigrant groups have become a permanent presence in both countries, and their educational and occupational profiles resemble each other. These parallels in immigration and ethnic stratification patterns notwithstanding, the social organization of schooling in the U.S. and Germany differs in important ways. Sociologists have long explored the within and between-school tracking processes typical of the U.S. and Europe, respectively. Both processes differentiate between rigorous academic, intermediate, and explicitly vocational "tracks." But the pervasiveness of differentiation between tracks differs, as does the method of assigning students, making the U.S. placement process more murky (Gamoran and Mare, 1989; Garet and DeLany, 1988; Hallinan, 1992; Lucas, 1999; Lucas and Gamoran, 2002).

In the U.S., students attend comprehensive schools and graduate from secondary school after 12 years, ${ }^{1}$ At which point they become eligible to enter the postsecondary system. ${ }^{2}$ Schools typically offer different academic "streams" or "ability groups" as early as first grade, a practice that becomes increasingly common as students progress to higher grades. By the time students reach 9th grade (high school), ability grouping practices within school are all but ubiquitous. Coursebased ability grouping has become the norm, replacing formal tracking over the past decades. By the mid1990s, the transition from track-based to course-based ability grouping within schools affected students in about $86 \%$ of all high schools (NCES, 1994). Yet, de- spite the ascent of course-based ability grouping, most American students still pursue clearly identifiable academic trajectories, a pattern also reflected in our data. Though NCES data suggest that few high-school students change tracks over time and that students usually choose/are placed in the same track across academic subjects, other research has found less stability of middle-and high-school placement patterns (e.g., Hallinan, 1992; Lucas, 1999).

Officially, student assignment is informed by prior academic performance and teacher recommendations. However, a significant body of research shows that parental involvement impacts student academic trajectories, regardless of teacher recommendation (Lareau, 1987, 2003; McNeal, 1999; Portes and MacLeod, 1996). Evidence also suggests that teacher perception of academic aptitude and social skills is shaped by students demographic background, creating cumulative disadvantage for students of color (Downey and Pribesh, 2004; Grant, 1998). Perhaps most importantly, access to coveted educational resources - including academically rigorous courses - varies widely across schools. In the U.S., schools are funded primarily via local property taxes, leading to well-known differences in resource levels. Since students typically attend the public school in their residential catchment zone, their ability to choose (or be assigned to) a school that offers rigorous academic courses depends on their family's ability to afford housing in more expensive areas.

In contrast, though elementary schools are comprehensive, Germany maintains rigid between-school tracking practices at the secondary level. Most pupils attend one of the three traditional, externally tracked types of schools; a pattern reflected in the GSOEP data we use. The type of school attended determines years of schooling/attainment-ranging from nine years for the Hauptschule/vocational, over ten years for the Realschule/intermediate, to thirteen years for the Gym-

1. The U.S. norm to offer a single exit credential affects drop-out rates, which are higher than in European countries like Germany. In contrast to the U.S., graduation age for students in Germany's lowest track coincides with the end of compulsory schooling regulations. Drop-out rates also differ consistently between ethno-racial groups. During the time period in question, U.S. dropout rates were $11 \%$ overall, with $7.5 \%$ among whites and over $25 \%$ among Latinos. Though overall drop-out rates in Germany have been consistently lower (at 8-10\% since the early 1990s), they also remain ethnically stratified, with 13\% of children of migrants failing to graduate from any of the secondary school tracks, compared to $\sim 7 \%$ of ethnically German students. Most drop outs in Germany come from the lowest, vocational track and from schools serving students with special needs (see FOCUS Online, 2010 and Baumert et al., 2003).

2. U.S. high school graduates technically become eligible to attend post-secondary institutions, regardless of course taking record or track attended. But admission into selective academic institutions tends to be limited to students with a record of taking rigorous academic courses (see College Board, 2011 and NCES, 2010). Thus, while the U.S. post-secondary system has experienced several decades of steady growth in enrollments, this expansion has been accompanied by increased stratification within higher education, leading to particularly strong growth rates among non-selective institutions serving part-time students seeking twoyear programs in applied fields (e.g., medical assistant, accounting, computer repair). In that sense, they resemble the Berufsschulen in Germany (which provide academic training side by side with apprenticeships) more so than a traditional college or university (Brint and Karabel, 1989, Dougherty, 1994, Karabel, 2005 and Rosenbaum, 2004). 
nasium/rigorous academic curriculum. Track placement typically occurs with the 5th grade, though some states and localities (e.g., Berlin) do not begin to track students until the 7 th grade, and placement can change until the 10th grade. However, though formally possible, few students switch tracks in Germany. About ten percent of secondary students changed tracks during the time frame we examine here. Among these, an equal proportion reportedly moved on to higher and lower tracks (Henz, 1997).

Beyond 10th grade, qualified students can attend the Gymnasium. ${ }^{3}$ Only those students who graduate from the Gymnasium qualify for admission to the university system (approximately $1 / 3$ of each cohort in the early 1990s). In the past few decades, the most desirable apprenticeships (financial, medical sectors) have increasingly gone to graduates from the elite track, and even apprenticeships in the trades now mostly go to students from the intermediate track (Realschule), thus de facto turning the vocational track into a dead end (Seifert, 1997). ${ }^{4}$

Track recommendations are partly based on student academic performance during elementary school, though research shows that background criteria also play a role: Parental cultural capital in addition to socioeconomic background structure decisions regarding children's transition to the highest track, the Gymnasium (DeGraaf, 1988). These recommendations are shared-and often negotiated - with parents, who submit them to secondary school principals at the schools where they seek admission. Despite the officially nonbinding character of teacher recommendations, enrolling a child in a particular school without the appropriate teacher endorsement remains difficult. The German system also differs from the U.S. in that pupil assignment is not tied to place of residence. Instead, students can attend any public school within the (city/county) school system. Rather than school buses, public transportation delimits what is logistically feasible for families and students.

This discussion suggests not only that the "sorting mechanisms" used in the U.S. and in Germany differ, but also that these systemic differences may moderate the extent to which specific types of parental resources, more or less directly linked to SES, affect track placement. This realization also informs our methodological decision to treat all identifiable tracks as distinct.

\subsection{Theoretical background}

To explain ethnic inequalities in educational outcomes, many researchers turn to micro-level status attainment factors measured by individual and family characteristics. Empirical studies support this perspective, suggesting that parental and family resources differ substantially between ethnic minority and majority groups. Alternatively, macro-level explanations see the lack of social mobility for underprivileged groups as the result of an educational system structured to reproduce existing class and ethnic inequalities (e.g., Oakes, 1985; but see Gamoran \& Mare, 1989). ${ }^{5}$ Following Powell et al. (2004), our own approach highlights crucial micro-macro interactions: We propose that the specific micro-level dynamics shaping ethnic patterns in student placement are themselves conditioned by institutional context, i.e., by the way the school system structures the track placement process. This quasiinteractional dynamic, schematically depicted below, suggests that the social organization of schools can affect the mechanisms creating ethnic stratification patterns by shifting which specific parental resources play a role in track placement (Buchmann and Dalton, 2002; Powell et al., 2004).

3. A comprehensive type of high school (modeled after U.S. high schools) also exists, called Gesamtschule. But it exists parallel to the traditional tracks in only a few German states, and it only affects a small proportion of students. Oswald, Baker, and Stevenson (1988) pointed out regional fluctuation in comprehensive school students, varying between $2 \%$ in populous southern states and $25 \%$ in (then) West-Berlin. Even students in these schools are encouraged to take the same level of courses to receive high school credentials oriented after the three traditional tracks.

4. It is not clear whether immigrant parents are aware of this long-term trend, which has accelerated for a long time. The vast majority of immigrant parents included in our sample arrived before the immigration reforms in 1980. Thus one might expect immigrant parents in Germany (especially Turks and Italians) to be familiar with the hierarchical nature of the system and the effect of track placement on occupational and social mobility (which, in turn, may shape how effectively they can deploy resources on behalf of their children). Research by e.g., Phalet and Schonpflug (2001) and Kristen (2002) seems to confirm this. They also note, however, that immigrant parents' preferences are also shaped by SES and gender norms. In other words, not all parents strive to place their children in the highest possible track. Unfortunately, the GSOEP lacks data on parental aspirations for their children, putting an empirical examination of this issue beyond the scope of this article.

5. Yet a third perspective looks for answers in how schools themselves are structured and the communities in which they are embedded. However, because the data sets employed here do not contain pertinent organizational/school-level or communitylevel data, we refer readers to the work of other researchers (e.g., Arum, 2000). 


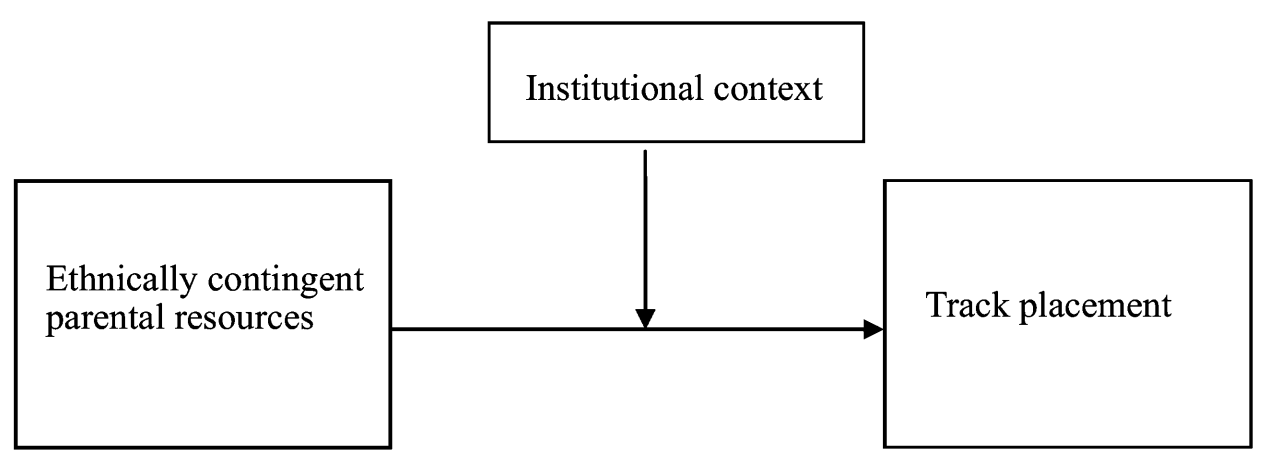

We conceptualize two types of parental resources: Those resources closely tied to economic and human capital, and those related to personal ties and networks. As is the norm, our analyses of the former take into account family dynamics, particularly the intergenerational transmission of resources through family structure, income, and parental education (Shavit \& Müller, 1998). Although some studies have shown that minority parents may allocate disproportionately more SESbased resources to promote their children's success in school, most scholars agree that such efforts are still limited by the unequal resources available to parents (Lareau, 2003; Powell and Steelman, 1989). Most important for our analysis, parental social networks may produce ethnically specific impacts even when activated in similar fashion (see Lareau \& Horvat, 1999), because whether and how parents can effectively assist their children's schooling may depend on the information they receive from ties to gatekeepers and the community at large (Bourdieu, 1977, 1986; Coleman, 1988; Granovetter, 1983).

While Coleman famously conceptualized parental networks in terms of social closure mechanisms that facilitate normative behavior, Bourdieu instead focused on the institutional basis of social relationships that can provide access to potential or actual resources and valuable information (Bourdieu, 1986:248-249). He considered access to such organizationally based ties as strongly derived from but not reducible to social class background. According to Bourdieu, because such ties are fundamentally tied to people's habitus, they reflect existing social hierarchies and thus help reproduce or exacerbate social inequalities. Similarly, U.S. research suggests that weak ties to institutional agents or "gatekeepers" play a key role in shaping educational outcomes (Carbonaro, 1998; Stanton-Salazar and Spina, 2003), and they do so in ethnically specific ways (Lareau, 1987; Royster, 2003; Stanton-Salazar and Dornbusch, 1995). This also mirrors insights from the sociology of organizations, which suggests that the effects of so-called "weak ties" become most noticeable when they cross primary and status groups (Granovetter, 1983). Focusing on weak ties to the community is particularly pertinent for our ethnic-group analyses, because it allows a possibility not foreseen by either Coleman or Bourdieu: Ties to gatekeepers can systematically reproduce/exacerbate inequalities or ameliorate them, depending on the group and the institutional context (Cheng et al., 2007; Jungbauer-Gans, 2004; Teachman et al., 1997).

How, then, might the ethnically specific effects of parental resources be conditioned by institutional context? Extant research tends to associate school systems that maintain explicit vocational tracks with more pronounced social reproduction effects. Conversely, comprehensive systems lacking a vocational component are perceived as producing less pronounced social reproduction effects (but see Shavit \& Müller, 1998). In fact, while the comparatively flat hierarchy within the U.S. secondary school system may attenuate the impact of SES-related resources, it is unclear whether differences in parental social ties further exacerbate ethnic inequalities. We might expect parents who establish ties to gatekeepers and who are involved in schools and their community to translate those weak ties into educational advantages for their children. Given the close-knit relationships that often exist in immigrant communities, this might work to the benefit of immigrants (Vega, 1990). Alternatively, the complexities involving course-based ability grouping may make it more difficult for underprivileged groups, especially immigrants, to navigate the system. Group differences in parental ties may indeed exacerbate educational inequalities, because the ethnic majority is typically a step ahead of immigrants and minorities in translating resources into educational advantage (Kao, 2004; Lareau, 2003). In other words, assuming that different ethnic groups compete for access to the most coveted educational tracks, we might expect white students to benefit from parental network resources more readily than Latino students, regardless of differences in SES (Lareau and Horvat, 1999; Stanton-Salazar and Spina, 2003). 
Regarding Germany, extant research does lead us to expect strong intergenerational social reproduction effects directly tied to parental SES. The empirical question is whether the transparency of the German track placement system enables parents to employ social ties in ways that exacerbate or attenuate ethnic inequalities. On the one hand, ethnically specific social ties may be so strongly tied to habitus that activating them does not translate into educational advantages for minority or immigrant students (e.g., Bourdieu, 1977; DeGraaf, 1988). On the other hand, if these comparatively weak ties indeed are not reducible to SES or habitus, they may play a compensatory role, and thus help attenuate (though not reverse) class-based social reproduction effects. If so, immigrants in Germany may be able to employ such ties more effectively, even though they report fewer community/gatekeeper ties (especially those crossing primary and status group boundaries) than any other group. In other words, the relatively straight-forward social organization of schooling in Germany may enable ethnic minority parents to compensate for socioeconomic disadvantages and mitigate ethnic inequalities in track placement (e.g., Cheng et al., 2007; Jungbauer-Gans, 2004; Teachman et al., 1997).

To illustrate why institutional context shapes the impact of community ties, we point out that schools do not exist in a vacuum: The U.S. system, which involves allday schooling, means most extracurricular and/or after-school activities are organized through schools (except in summers). In contrast, German schools let out between 1 and $3 \mathrm{pm}$, offer limited extracurricular options in the afternoons, and none in the evenings. To participate in after-school activities, families join nonschool based community organizations akin to YMCAs ("Sportvereine") or music schools, where they are likely to encounter adults not affiliated with their child's school. While resulting weak ties may combine both compensatory and reproductive functions, identifying how the institutional context shapes which types of parental resources play the biggest role in track placement has important implications for educators and policy makers alike.

\section{Data, methods, and measures}

\subsection{Data}

Empirical research that explores how institutional context moderates the way different types of parental re- sources shape educational trajectories remains rare. The challenge of finding multi-country datasets that contain comparable measures in part accounts for this empirical gap. We employ data from the National Educational Longitudinal Study (NELS) and the German Socio-Economic Panel (GSOEP) to examine how institutional context may shape reproduction dynamics. Both datasets contain key information about students' track placement, ethnicity, and various measures of parental SES and network resources. Table 1 details the measures included in our analyses. NELS is one of the most comprehensive panel datasets on secondary students in the U.S. We focus on the 1988-1992 longitudinal surveys, because they provide students' background information in the base year, and information about track placement (our dependent variable) is based on 12th-grade transcripts (1992). After applying multiple imputations to missing data to preserve cases, ${ }^{6}$ our final sample size for the U.S. analyses is 7728 (6898 Caucasians, 830 Latinos).

Similarly, we pool data from different waves of the GSOEP (1990/1991, 1994/1995), known for high response rates and data quality, and for being the largest panel dataset including immigrants in Germany. In this case, our dependent variable is derived from the 1991 and 1995 waves. Whenever possible, we employ temporally antecedent independent variables from the 1990 and 1994 waves. Choosing the two waves separated by four years prevents individual students from being included more than once.

For the GSOEP analyses, we constructed an age heterogeneous sample that includes students age eleven to sixteen. Cheng et al. (2007) constructed their sample identically, whereas Büchel (e.g., Büchel and Duncan, 1998; Büchel and Wagner, 2000/2001) extracted a sample of 14-year olds from the 1984-1994 waves. Our overall results mirror those reported in both studies. We follow the approach used in Cheng et al. (2007), because small sub-samples in the latter would preclude us from pursuing ethnically specific analyses. After applying multiple imputations to missing data to preserve cases, our sample size for Germany is 675 (470 ethnic Germans, 205 non-Germans).

Although NELS and GSOEP allow us to draw on similar measures of variables for cross-national comparison, data limitations do constrain the scope of our analysis. Recent cross-national datasets like PISA and TIMMS have greatly expanded the potential of comparative-international analysis that relies on identical

6. To preserve cases, we employ the MICE ("multiple imputation by chained equations") procedure suggested by Steff van Buuren (see Royster, 2003) to impute eight cases in the German data and 1064 cases in the U.S. data with missing values on independent variables. To ensure unbiased estimates in final analyses, our imputation models include predictors in our multivariate analyses and, in the case of the U.S. data, additional information from students' family SES background in 1988-1992. 
Table 1. Variable descriptions and matrices.

\begin{tabular}{|c|c|c|c|c|}
\hline \multirow[b]{2}{*}{ Variables } & \multicolumn{2}{|l|}{ United States } & \multicolumn{2}{|l|}{ Germany } \\
\hline & Descriptions and matrices & Waves & Descriptions and matrices & Waves \\
\hline \multicolumn{5}{|l|}{ Dependent variable } \\
\hline Track placement & $\begin{array}{l}1=\text { Vocational } \\
2=\text { Academic } / \text { Intermediate } \\
3=\text { Rigorous Academic } \\
\text { (transcript based) }\end{array}$ & ‘92 & $\begin{array}{l}1=\text { Hauptschule/Vocational } \\
2=\text { Realschule/Intermediate } \\
3=\text { Gymnasium } / \text { Academic }\end{array}$ & ‘91, '95 \\
\hline
\end{tabular}

Family SES resources

\begin{tabular}{|c|c|}
\hline Annual family income & $\begin{array}{l}1=\text { Latino } \\
0=\text { White } \\
1=\text { Mexican Latino Origin } \\
0=\text { Non-Mexican Latino } \\
\$ 1000\end{array}$ \\
\hline Highest parental education & Years \\
\hline Household size & \# persons in the household \\
\hline \multicolumn{2}{|l|}{ Parental network resources } \\
\hline Visits with family & $\begin{array}{l}\text { How frequently parent and teen } \\
\text { attended family social functions, } \\
\text { ranged from } 1 \text { (never) to } 4 \text { (frequently) }\end{array}$ \\
\hline Sports & $\begin{array}{l}\text { How frequently parent and teen } \\
\text { worked on a hobby or play sports, } \\
\text { ranged from } 1 \text { (never) to } 4 \text { (frequently) }\end{array}$ \\
\hline Volunteers & $\begin{array}{l}\text { Parent or spouse acted as a volunteer } \\
\text { at the school, } 1=\text { yes and } 0 \text { otherwise }\end{array}$ \\
\hline Attends religious services & $\begin{array}{l}\text { How frequently parent and teen } \\
\text { attended religious services, ranged } \\
\text { from } 1 \text { (never) to } 4 \text { (frequently) }\end{array}$ \\
\hline Host language proficiency & $\begin{array}{l}\text { Composite variable from both } \\
\text { parents' ability to speak and write } \\
\text { English, ranged from } 2 \text { (poor) to } \\
10 \text { (very good) }\end{array}$ \\
\hline
\end{tabular}
'92 1 = Non-German '90-'95

Parental network resources

‘92 How frequently parent reported ‘90, ‘95 visiting family, ranged from 1 (never) to 4 (frequently)

'92 Parents' sports activities, ranged from '90, '94 1 (never) to 4 (weekly)

‘88 Either parent volunteers, $1=$ yes $\quad$ '90, ‘94 and 0 otherwise

‘92 Either parent attends religious ‘90, ‘94 events, ranged from 1 (never) to 4 (weekly)

'88 Both parents' ability to speak or '91, '95 write German, ranged from 2 (poor) to 10 (very good)

Other control variables

$\begin{array}{llll}\text { Female } & \begin{array}{l}1=\text { Yes } \\ 0=\text { Otherwise }\end{array} & 92 & \begin{array}{l}1=\text { Yes } \\ 0=\text { Otherwise }\end{array} \\ \begin{array}{l}\text { Standardized prior school } \\ \text { achievements }\end{array} & \text { School grade composite } & ‘ 88 & -\end{array}$

Data sources: The National Education Longitudinal Study (NELS) of 1988-1992 (United States) and the German Socio-Economic Panel (GSOEP) of 1990-1991, 1994-1995 (Germany).

measures across countries (e.g., Jungbauer-Gans, 2004). However, even PISA and TIMMS lack the type of information necessary to examine how parental network resources affect educational outcomes. While this leaves the GSOEP the best available dataset for our analysis, the GSOEP has a significant drawback: It does not con- tain measures of children's prior academic achievement. Facing the dilemma between waiting for perfectly comparable data or making the best of what we have, we perform supplementary analysis using the ITCV (or "Impact Threshold for a Confounding Variable") technique developed by Frank (2000). It allows 
us to test the robustness of our findings in the presence of the missing measure as a confounding variable (see Appendix A). We readily acknowledge that, despite these methodological remedies, our GSOEP models are inferior to the NELS models because the former lack a control measure for students' prior achievement. Our analyses should be viewed as illustrative of how institutional context can shape the way parental resources affect academic outcomes.

\subsection{Measures}

\subsubsection{Track placement}

Track placement is our dependent variable. Extant research generally treats tracks as a binary or ordinal variable. This forces the effects of independent variables on the two higher tracks (from intermediate to academic and vice versa) to equal those on the two lower tracks (between vocational and intermediate). Recent U.S. literature suggests that this assumption may be problematic (Arum and Shavit, 1995; Royster, 2003; Stanton-Salazar and Spina, 2003). To examine how parental resources affect track placement across and within countries more accurately, we code track placement as a nominal variable with three categories: vocational/Hauptschule, intermediate/Realschule, and rigorous academic/Gymnasium. The U.S. measure originates from 1992 student transcripts, when respondents were seniors in high school. The German track placement measure is based on parents' report of the type of secondary school their child attends. ${ }^{7}$ Table 2 presents distributions and weighted descriptive statistics.

\subsubsection{Nationality/ethnicity}

In country-specific models, we include a dichotomous variable measuring whether the students have immigrant status. Because patterns in immigrant communities in both countries are heavily influenced by specific dominant groups, we also conduct ethnically specific analyses for each country, where we further examine the effects of parental resources variables, respectively, on ethnic majority and immigrant students. For each ethnic group model, we include a dichotomous variable measuring the dominant immigrant group, with Mexican origin coded as 1 in the U.S. analyses and Turkish descent as 1 in the German models.

\subsubsection{Family SES resources}

Family income is measured by thousands of USD/German Marks per year. Parental education equals years of schooling of the parent with the highest educational attainment level. Both should be positively related to track placement outcomes. We also include household size to account for potential resource dilution dynamics (Powell et al., 2004; Shavit and Pierce, 1991). In addition, we control for gender ( $1=$ female).

\subsubsection{Parental network resources}

We distinguish parental network resources within extended families and outside of family circles. We gauge the strength of parental ties with extended family members via the frequency of parents visiting family members or attending family social functions. We measure parental involvement in community-based organizations related to sports and volunteerism as well as participation in religious activities. Family and network-related activities are measured on a 4-point scale $(1=$ never, $4=$ frequently $)$. NELS measures volunteerism by whether (one of) the parents volunteer at school. The GSOEP measure gauges parents' volunteer activities in general $(1=$ yes $)$.

Finally, being more acculturated may lead immigrant families to experience intergenerational "downward assimilation." Alternatively, 2nd- and 3rd-generation immigrants may experience "upward assimilation" because they are better able to build ties to institutional agents who can help them navigate the system to their children's advantage (Bankston, 2002, 2004; but see Waldinger \& Feliciano, 2004). Because the way parental acculturation affects children's educational outcomes appears difficult to predict, we propose that the effect may indeed be institutionally contingent (Büchel and Duncan, 1998; Rumberger and Larson, 1998). Because speaking the host language is a proxy for parental acculturation in the host society, we measure parental acculturation using immigrant parents' proficiency in the

7. In the U.S. data, we excluded 3675 students with ambiguous school tracks and 1207 students without sufficient information in the data to do multiple imputations. These students are more likely to be Latino, and have lower family income, parental education, school performance, and larger household size (all $\left.p^{\prime} \mathrm{s}<.05\right)$. In supplementary analyses, we collapsed ambiguous school tracks as "others," included them as another outcome category in multinomial logit analyses, and used IIA tests to see whether or not omitting these cases from our analyses may affect our findings. The results suggest that we can safely exclude this "other" category from analyses (but also see Cheng \& Long, 2007). Similarly, the GSOEP-based Gymnasium track sub-sample also includes a small number of students from the Gesamtschule (approximately 1\% of the total sample). Supplementary analyses show that excluding these students from the sample does not alter substantive findings. Because of the generally small sample size, we opted to keep these cases. Alternative runs available on request. 
Table 2. Weighted summary statistics for U.S. and German samples.

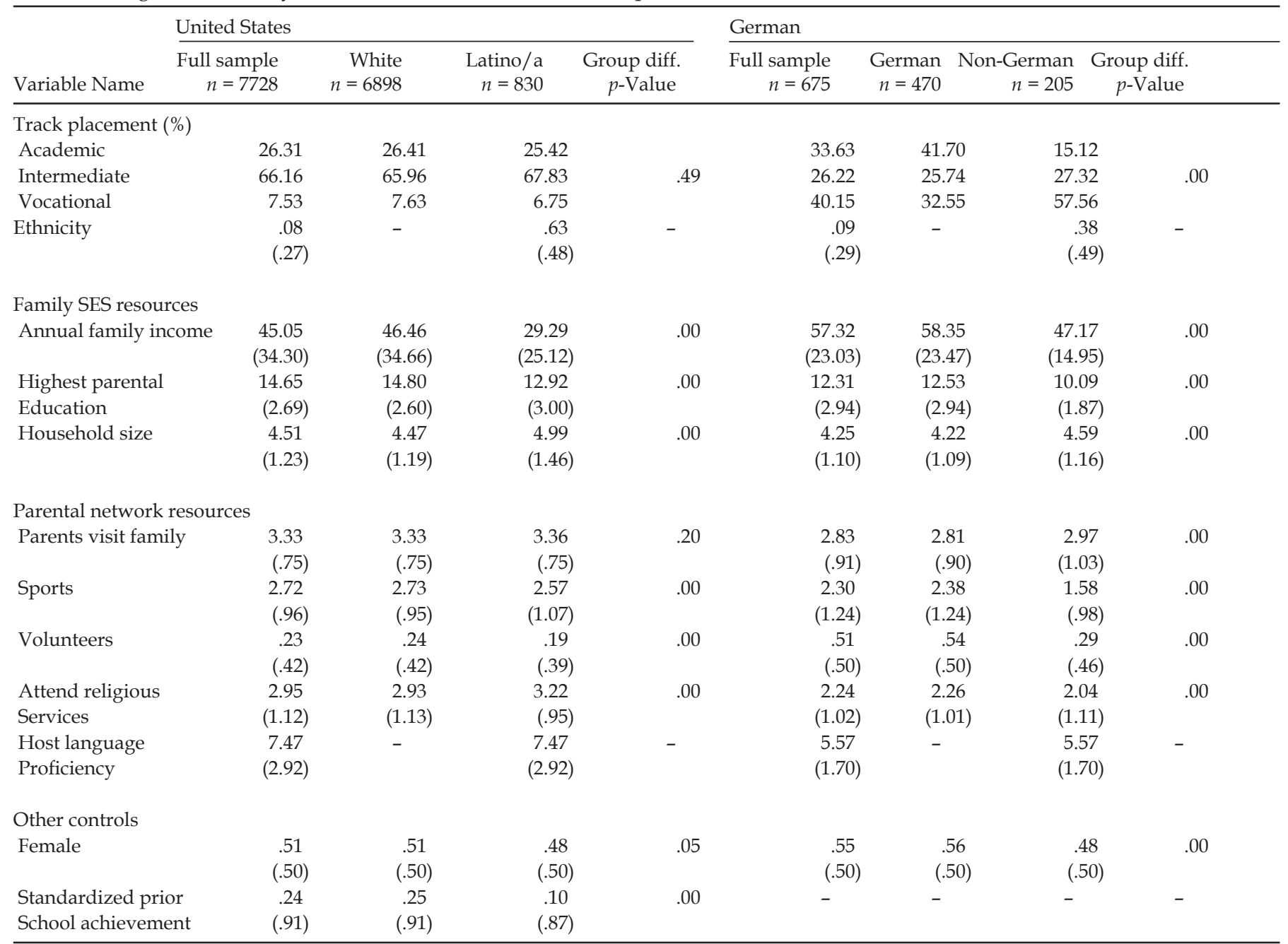

Standard deviations are in parentheses. $p$-Values for track placement are based on Pearson $\chi^{2}$ with 2 degrees of freedom. All other $p$-values are based on $t$-tests.

Data sources: The National Education Longitudinal Study (NELS) of 1988-1992 (United States) and the German Socio-Economic Panel (GSOEP) of 1990-1991, 1994-1995 (Germany).

host language $(2=$ poor, $10=$ very good $) .{ }^{8}$ We discuss alternative parental resource measures in endnotes. ${ }^{9,10}$

\subsection{Analytical strategies}

Following Breen and Jonsson (2000) and our coding of track placement as a nominal outcome, we employ mul- tinomial logit (MNL) regression, which has been commonly used in other fields and is gaining acceptance in educational research (e.g., Brooks et al., 2006; Long and Cheng, 2004). Generally, a sample size over 500 is considered adequate for MNL analyses and that at least ten observations are required for each parameter included. Thus, we pool immigrants and ethnic majority samples

8. Metric: The data contain separate measures for how well parents can speak and write the host language (English in NELS; German in GSOEP). Each of those variables ranges from $1=$ poorly to $5=$ very well. The sum of these variables was used to measure how well parents speak/write the host language, leading to the final measure with a range of 2 (poor) to 10 (very good).

9. Elsewhere, we included parental time spent with the focal child, which did not produce statistically significant effects $(p<.10)$ nor change other patterns reported here. Because our substantive discussion largely focuses on parental network ties rather than a broader umbrella concept of "parental involvement" we exclude it from presentation.

10. Though both datasets provide information about residence characteristics of immigrants, measures are plagued by missing values. Analyses not reported here show that parental residential histories in the host country do not affect Latino children's track placement. Similarly, parents' plans to stay in Germany failed to have an effect on non-German children's track placement. 
together whenever possible. Another benefit of this analytical strategy is that it also allows us to directly compare the differential effects of parental resources measures across ethnic groups. ${ }^{11}$

We conceptualize our MNL models as the simultaneous estimation of binary logits for all pairs of outcome categories by imposing certain logical constraints among parameters (see Long \& Cheng, 2004). For each pair of options $m$ and $r$, the log of odds is a linear combination of independent variables,

$$
\ln \Omega_{m \mid r}=\mathbf{x}_{i} \boldsymbol{\beta}_{m \mid r}
$$

where $r$ is the reference category, and $\boldsymbol{\beta}_{m \mid r}$ is a vector of coefficients indicating the effects of independent variables on outcomes $m$ vs. $r$. We use the intermediate track as the reference category and present two sets of coefficients. This allows us to see the effects of parental resources factors on pairs of adjacent tracks without imposing the ordering among outcome categories. Our analyses proceed in three stages. Table 2 examines bivariate country and ethnic differences in parental resources and track placement. Table 3 employs MNL to examine the effects of parental resources on track placement in the U.S. and in Germany. Table 4 and Table 5 compare the ethnically specific effects on track placement of immigrants (non-Germans, Latinos) and the ethnic majority (Germans, Caucasians) within each country. For all MNL analyses, we present the raw coefficients and several model fit statistics, weighted and controlled for school and household clusters.

\section{Results}

\subsection{Descriptive statistics}

Table 2 indicates that no perceptible ethnic track placement differences exist in the U.S. In contrast, track placement practices in Germany differ strongly between the ethnic majority and immigrants, leading non-Germans to be underrepresented in the academic and over-represented in the vocational tracks. Bivariate patterns confirm previous research suggesting that the U.S. system mitigates social reproduction dynamics, whereas the external track placement tradition in Germany facilitates class reproduction across ethnic lines (Jungbauer-Gans, 2004; Shavit and Müller, 1998).

Several parental resource trends also stand out. First, while immigrants in both countries exhibit stron- ger extended family ties than ethnic majority families, the group difference in the U.S. is not significant. This suggests that the commonly voiced assumption about "familism" in Latino communities as fundamentally distinct from mainstream American practices deserves further scrutiny (Vega, 1990). Second, significant group differences exist for all other independent variables. These group patterns are mostly predictable, especially for SES-based resource measures. Third, except for the attendance of religious services in the U.S., immigrant parents tend to display lower levels of community involvement. These differences are especially sizeable in Germany. This may suggest that building weak social ties is more difficult for non-Germans than for their German counterparts. These patterns may also foreshadow how institutional context shapes the way parents of different groups activate family resources to improve their children's track placement odds in schools.

\subsection{Multivariate analyses}

\subsubsection{Country-specific patterns}

Table 3 addresses the question: How does institutional context shape the way parental resources affect track placement in the U.S. and in Germany? In the U.S., we see that when we hold parental SES and network resources constant, being Latino decreases the odds of attending the vocational track $(p<.01)$, but does not reduce the odds of attending the academic track (Column 1). This pattern persists in Column 3 when we control for prior academic achievement. In light of the lower average parental resources reported among Latinos (Table 2), this finding implies that in the U.S., immigrant students are not entirely disadvantaged in terms of track placement, but their odds of attending the coveted academic track remain dampened. In this sense, our results extend work by Lucas (1999) and associates, which demonstrated that the ethnic disadvantage experienced by African Americans dissipates once we take differences in SES-based resources into account. Similarly, German analyses show that the track placement disadvantage experienced by immigrants in Germany shown in descriptive statistics disappears in multivariate analyses (Table 3, Column 2). This suggests that ethnic inequality in track placement is largely the result of group differences in parental SES and network resources. Note that, far from indicating that ethnic inequality patterns are trivial in Germany, this finding further buttresses extant research that documents the strong SES/class-based foundation of ethnic inequality in Germany.

11. To compensate for the loss of efficiency associated with MNL, we use .10 as the threshold for (two-tailed) significance tests. We found no violation of the IIA assumption in our models based on the results of IIA tests. 


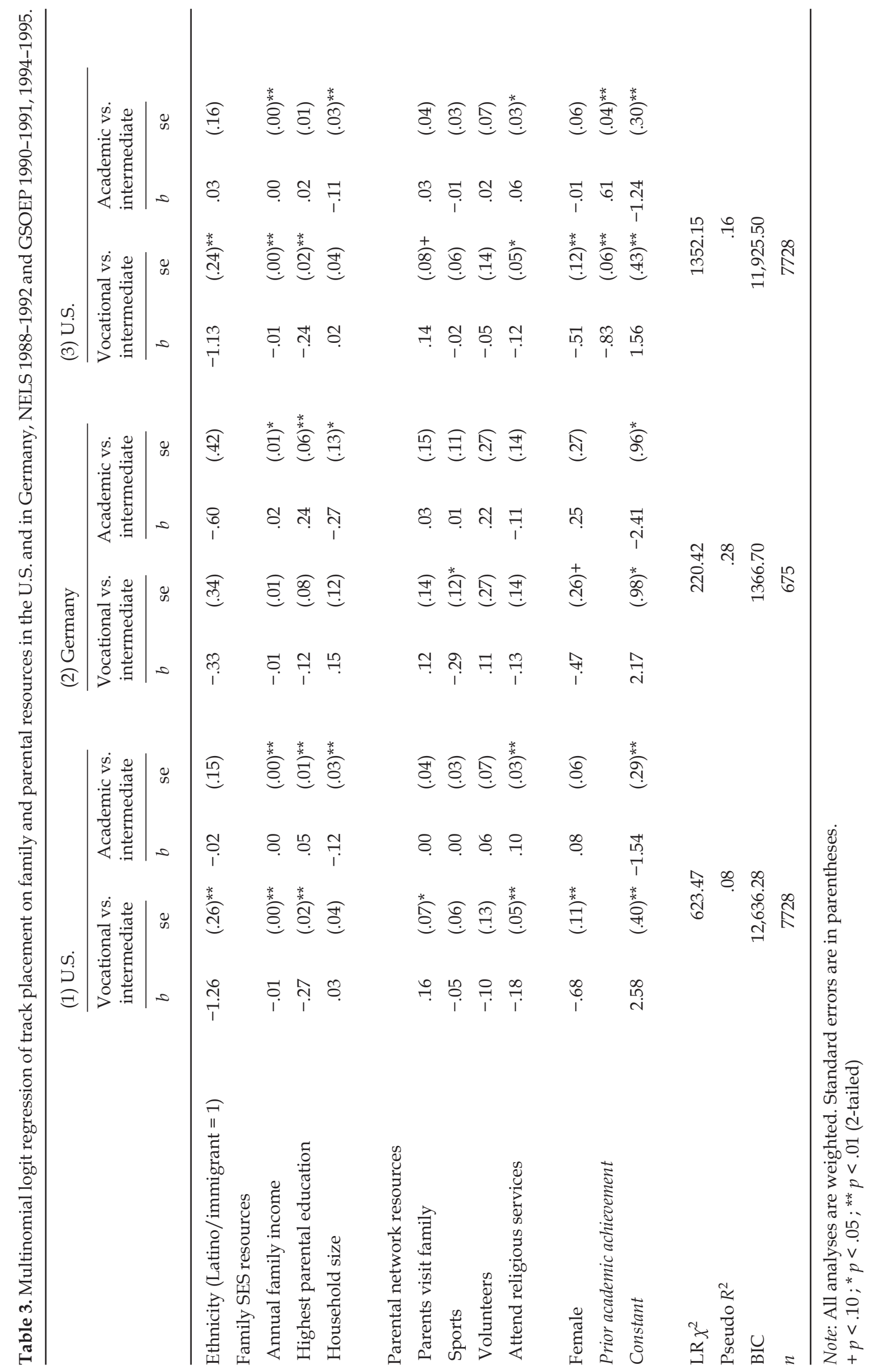




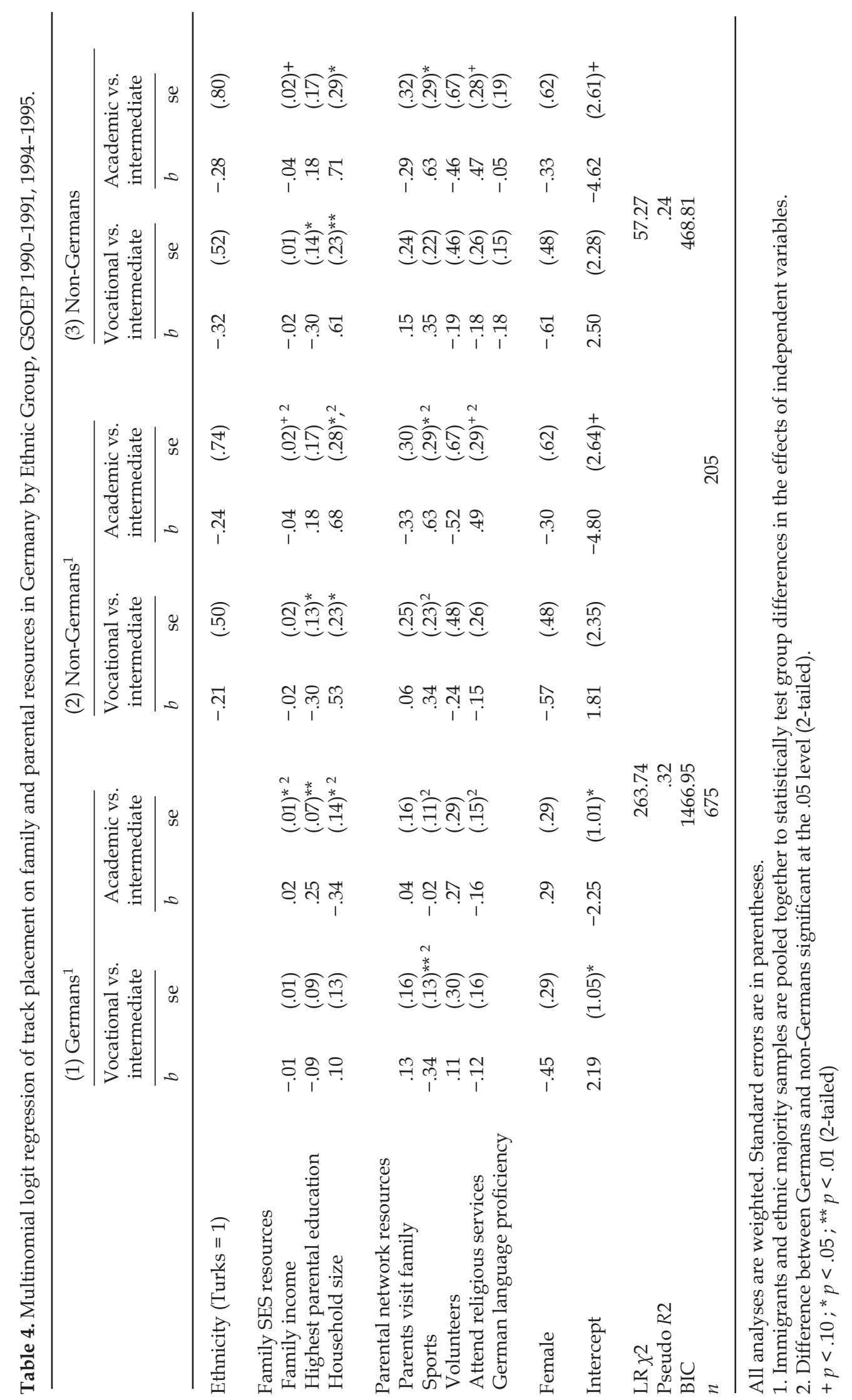




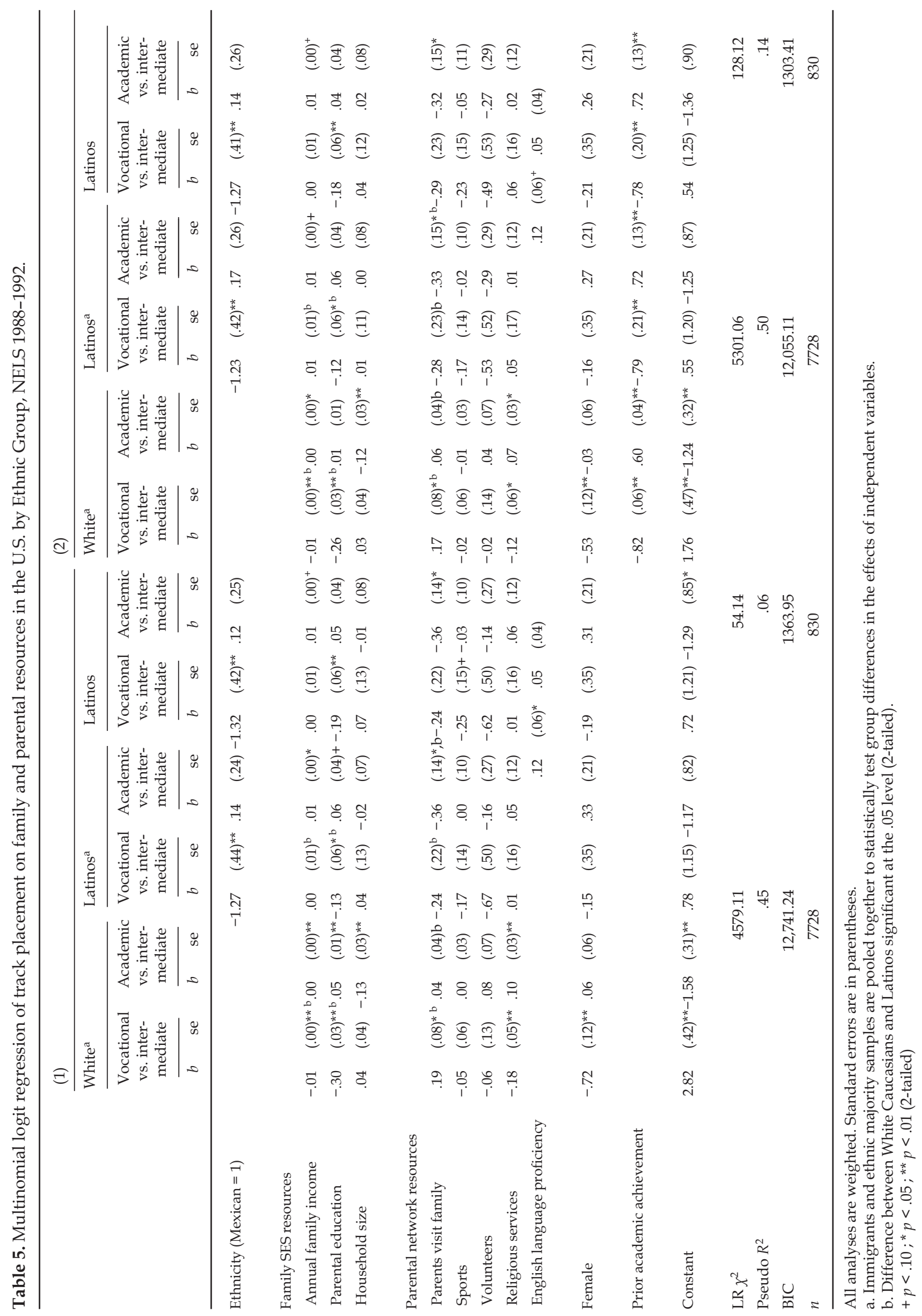


As expected, analyses suggest that higher family income, higher parental education, and smaller household size increase the odds of attending the academic track and mostly decrease the odds of attending the vocational track in the U.S. Although the effects on the odds of attending vocational vs. intermediate tracks in the German analysis are not statistically significant, the general directional pattern of logit coefficients is consistent with that of the U.S. analysis. Because statistical significance is partially a function of sample size, we tentatively conclude that family resource measures generally pull students from lower to higher tracks. This conclusion will hardly surprise stratification researchers. However, it also suggests that although the informal, coursebased ability grouping associated with the U.S. system may have reduced the appearance of a highly stratified system that produces educational disadvantage for ethnic minorities, beneath the veneer, class reproduction dynamics continue to create adverse effects for immigrant students.

Table 3 also illustrates the effects of parental network resources on track placement. We find that visiting extended families increases the odds of attending vocational vs. intermediate tracks (similar $b$ 's ranging from .12 to .16). Though this effect echoes findings from U.S.-based qualitative studies (Lareau, 2003; Royster, 2003), the effect in the German analysis is not statistically significant at the .10 level. Regarding parental ties to the communities, we observe that in Germany, students whose parents are actively involved in sports organizations are less likely to attend the lowest track ("Hauptschule"). Similarly, the U.S. analysis shows that attending religious services produces strong and consistent effects on track placement that mirror the class-based effects discussed above, buffering students against placement in the vocational track while also boosting their chance of attending the highest track. Although our measures do not allow us to pinpoint what activities take place during religious services or sports activities that might produce these effects, we know that sports organizations have traditionally been identified with different status groups in German society (see Tönnies, 1922; Weber, 1956). In the U.S., religious congregations may have played a comparable role (Wuthnow, 2002). If so, these findings suggest that institutional context shapes which specific parental network resources come into play in affecting students' track placement.

We also note the contrast between the effects of parental network resources within and outside of family circles. Organizational and network theorists will point out that the positive effects of involvement in religious (in the U.S.) or sports organizations (in Germany) reflect the "strength of weak ties" typically associated with membership in voluntary associations, especially those designed to bridge (rather than reinforce) status boundaries (Granovetter, 1983; Putnam, 2000). In contrast, the negative, at most marginally significant effects of extended family ties suggest that closely knit, homogenous networks with extended family members may potentially reduce contact opportunities with the "institutional agents" in the larger communities and thus prevent parents from gaining more useful information for their children's schooling (Büchel and Duncan, 1998; Cheng et al., 2007). We suspect that these empirical patterns may be further refined once we take ethnic-specific patterns into consideration. In particular, given the unbalanced proportions of ethnic majority and minority students in both the German and the U.S. samples, the patterns displayed in Table 3 may reveal more about the ethnic majority than about immigrant students.

\subsubsection{Ethnic patterns}

The ethnically specific analyses in Table 4 and Table 5 address our final research question: How does institutional context shape the way parental resources affect children's track placement in ethnically specific ways?Table 4 presents the results for Germany. For ethnic Germans, we observe that more SES-based resources increase the odds of attending academic vs. intermediate tracks, and participation in sports organizations decreases the odds of attending the vocational track (all $p^{\prime} s<.05$ ). As expected, the patterns for ethnic Germans mirror those reported in Table 3 . This suggests that comparative research focusing only on national patterns as a whole may present a picture dominated by the ethnic majority sample and, as a result, may fail to capture how the institutional context conditions the mechanisms affecting immigrant students' track placement.

How does ethnicity affect track placement odds in this context? Just as minority status per se had no significant impact on track placement odds in Germany (see Table 3), the odds of ethnic Turks attending a particular track are no different from those of other immigrant groups, once we control for differences in family resources (see Table 4). Moreover, we see in Columns 2 and 3 that while higher parental education buffers non-German students from attending the vocational track $(p<.05)$, it does not boost rigorous academic placement odds as it did for Germans. Yet, note that, differences in the size of coefficients in Columns 1 and 2 notwithstanding, group differences are not statistically significant. 
Surprisingly, family income has a marginally negative effect on immigrant students' odds of being placed in the academic track $(p<.10)$. In other words, holding parental networks constant, higher SES background may push immigrant students from both vocational and academic tracks towards the intermediate track. Simultaneously, we observe that an increase in household size promotes immigrant students' odds of attending the academic vs. the intermediate tracks $(b=.68, p<.05)$. At first glance, this result appears counterintuitive, because much prior research has shown that additional family members tend to dilute the amount of tangible (e.g., financial) and intangible (e.g., time) resources parents can provide for their children and thus may influence children's educational outcomes. However, other scholars have demonstrated that resource dilution dynamics are highly contextual and group-specific and may be most pronounced among ethnic majorities in wealthy countries (see Buchmann and Dalton, 2002; Powell et al., 2004). Overall, our analysis suggests that, in Germany, SES-related resources have a less pronounced impact on track placement odds among immigrants than on the ethnic majority's odds. Most likely this pattern results from the comparatively limited variation in SES among non-Germans in the sample (see Table 2).

If family SES does not help immigrant students increase the odds of attending the elite academic track, what does? Our analysis suggests that adult sports and ethno-religious activities serve a much-needed compensatory function, improving the odds that non-German parents can place their children in the rigorous academic track (Teachman et al., 1997). Taken together, our findings suggest that in school systems with overt tracking mechanisms, SES-based resources exacerbate how schools create social reproduction effects. Thus, immigrant parents, who are often clustered in lower SES groups, may be unable to directly capitalize on SES resources to help their children. Instead, immigrant parents rely on network ties to the community at large to promote their children's educational opportunities. Thus, parental SES and network resources display a pronounced, institutionally and group-specific influence on track placement patterns.

To contextualize these findings, we note that, unlike the U.S., where children's afternoon sports activities are often organized by schools, families in Germany participate in "Sportvereine," local associations to which social scientists have long ascribed an important role in social reproduction. Historically, each status group in a given community (e.g., farmers, workers, petite bourgeoisie) had its own "Sportvereine," though these distinctions no longer hold. Quite possibly, immigrant families' membership in secular and religious associations enables them to activate so-called "weak ties" to institutional agents outside of the school system (clergy, community leaders) who can help them navigate an educational system with which they are generally unfamiliar. This lends support to prior research involving both the U.S. and the Germany, which shows that ties to institutional agents are particularly scarce - and thus even more pertinent-for underprivileged groups (Jungbauer-Gans, 2004; Royster, 2003; Stanton-Salazar and Dornbusch, 1995; Stanton-Salazar and Spina, 2003).

Table 5 contains the ethnically specific analysis for the U.S. sample. Regarding whites, we find that more SES resources generally steer students away from the vocational track while also promoting their chances for placement in the rigorous academic track. Extended family ties significantly increase the odds of vocational vs. intermediate track placement, whereas families who attend religious services lower the odds of vocational track placement and increase the odds of attending the academic track. Once more, these effects mirror the country-specific patterns already displayed in Table 3. This is not surprising, as white students make up the bulk of cases in the U.S. sample.

For Latinos, a different picture emerges. Compared to the Caucasian model, SES-related resources produce overall similar tracking effects, but at lower significance levels. Because our Latino subsample is sufficiently large $(n=830)$, this finding may reflect more about the limited availability of SES-based resources to Latino families. Our multivariate analysis also reveals that, within the pan-ethnic Latino category, being Mexican decreases the odds of vocational vs. intermediate track placement $(b=-1.27, p<.01)$. This pattern persists in analyses controlling for English language proficiency, prior academic achievement, or including both (see second "Latino" model under Column 2). This suggests that, when Latino students have similar SES backgrounds, being Mexican per se is not a disadvantage in track placement. This, again, supports prior U.S.-based research that the minority track placement disadvantage disappears once we take SES-differences into account (Gamoran and Mare, 1989; Lucas, 1999; Lucas and Gamoran, 2002).

Again, similar to whites, strong ties to extended family members are associated with attending lower tracks for Latinos. However, unlike for whites, extended family ties affect Latinos by decreasing their odds of attending the rigorous academic track $(b=-.36, p<.05$; Column 1), rather than increasing their vocational track odds. This effect persists when we take into account children's prior achievement and parents' English profi- 
ciency. We also find that parents' English language proficiency increases minority students' odds of attending the vocational track. This may suggest that Latino children's educational attainment decreases as their families become more acculturated. While not conclusive, our results may tap into a trend towards "downward assimilation" observed by several other researchers, especially with respect to educational outcomes among 2nd and 3rd-generation Latinos (Bankston, 2002, 2004; but see Waldinger \& Feliciano, 2004).

Otherwise, our Latino analyses suggest that parents' network ties to the community at large have little influence on their children's track placement. Given that immigrant families in the U.S., on average, also have fewer SES resources, this lack of compensatory effects related to immigrant parents' network resources creates a glaring contrast to Table 4 above (Germany). In combination with other reproduction effects, our findings may imply that course-based ability grouping practices typical in the U.S. can reduce the semblance of outright classbased social reproduction. But in their complexity and opaqueness, they may also cause additional difficulties for immigrant groups who need to navigate the school system. As a result, differences in SES-based resources as well as parental social ties to gatekeepers in the community play key, distinct roles in reproducing social inequalities along ethnic lines (Bourdieu, 1986; Granovetter, 1983; Royster, 2003; Stanton-Salazar and Spina, 2003).

\subsection{How comparable are our findings, and how robust?}

As noted earlier, the GSOEP does not contain a measure of prior academic achievement. This raises questions about the potential effects of omitted variables in our analysis. Would our findings for Germany persist if we controlled for prior achievement? To that end, we performed ancillary analyses using the ITCV procedure, a technique designed to assess the degree to which empirical findings are affected by the presence of an omitted variable (see Appendix A; Frank, 2000; for empirical works using ITCV in similar situations, please see Cheng et al., 2007). Based on the approximate reference distribution formed by "actual impacts of existing covariates," results suggest that the numbers of observed estimates of impact (" $k$ ") that are larger than a positive ITCV or smaller than a negative ITCV for each of the co- efficients under assessment range from 0 (more robust, such as "sports organization" in Column 2 of Table 3 in the vocational/intermediate equation) to 2 (less robust, such as "household size" in Column 2 of Table 3 in the academic/intermediate equation). In other words, the probability that adding prior achievement as an additional control might affect our conclusions regarding patterns observed in Germany is generally low.

Overall, our results indicate that, just like in the U.S., our findings for the key variables measuring parental SES and network resources are quite robust, for all groups, and in both countries. ${ }^{12}$

\section{Conclusion}

Our analyses address a question of key importance to comparative stratification researchers: How does institutional context moderate the way family and parental resources affect track placement by ethnic group? To illustrate the importance of institutional context, we analyze panel data from national surveys conducted in Germany and the U.S. and conduct multinomial logistic regressions by country and by ethnic group.

Our multinomial logistic regression results comparing both countries (Table 3) indicate that, once we take parental resources into account, being Latino in the U.S. buffers students from attending the vocational track. But it does not increase their chances of attending the academic track. At the same time, more family SES-based resources generally pull students from lower to higher tracks. These results suggest that, although being an immigrant minority itself does not create a disadvantage in students' track placement odds (see Lucas, 1999), minority children's educational opportunities are still dampened by limited access to resources. Furthermore, our analyses suggest that the effect of ethnicity on placement odds in Germany is a function of social class differences. In other words, we find ethnic group effects in the descriptive statistics but not in the regression analyses, because the socio-economic background of immigrants in Germany is systematically lower and more homogenous than among Germans. This finding provides additional support to a long line of research that has documented the strong and persistent SES/class-based foundation of ethnic inequality in Germany. ${ }^{13}$

12. ITCV was originally developed in the context of OLS regression. Goodman (1978) suggests that, when a binary dependent variable is not highly skewed, a Linear Probability Model (LPM, an OLS model for binary outcomes) and a binary logit model typically yield consistent findings. This implies that ITCV can be applied to binary outcomes using LPM in some circumstances (Cheng et al., 2007). Because MNL models are quasi-equivalent to a series of less-efficient binary logit models (Long, 1997), we applied the ITCV procedure by first performing LPM analyses to pairs of track placement outcomes.

13. We thank an anonymous reviewer for asking us to reflect on the fact that, in PISA reports, Germany stands out as a highly un- 
Ethnically specific analyses within both countries (Table 4 and Table 5) enable us to identify group-specific nuances regarding which specific parental resources shape track placement odds. It appears that trends commonly identified as institutional- or country-specific, in fact, primarily capture dynamics that apply to ethnic majorities. Regardless of how the institutional context formally structures access to credentials, the ability to translate SES-related resources into educational advantage is particularly pronounced among ethnic Germans and whites in the U.S., in part because of the limited availability of these SES resources to immigrant families. This leads to even greater ethnic differentiation in educational trajectories.

Institutionally contingent ethnic differences in how parental resources shape track placement become even more prominent when we turn our attention to family and community ties, i.e., resources not directly tied to SES background. In our data, extended family ties have no measurable impact on track placement in Germany. In the U.S., such ties actually increase vocational track placement odds among whites and "cool out" Latinos' academic trajectories. This contradicts much existing research on the importance of intra-familial dynamics in determining educational outcomes (Carbonaro, 1998; McNeal, 1999). Instead, our findings show that parental community ties play a crucial role in the reproduction of social inequalities - but that the specific mechanisms differ by group and by country. We propose that parents' community ties affect educational outcomes because such ties can enable parents to bridge status group differentials and access gatekeepers (Stanton-Salazar and Dornbusch, 1995; Wuthnow, 2002). While this idea goes back to classic sociological theory (Weber, 1956), it has been championed and further developed more recently by Bourdieu $(1977,1980)$ as well as Granovetter (1983) and associates.

More specifically, in the U.S., parental involvement in religious activities tends to keep white children out of the vocational track while boosting their placement in the highest track. This pattern persists even when we adjust for prior achievement. Thus, our findings suggest that U.S. mainstream religious organizations may play a key role in the reproduction of social inequalities, en- abling whites to activate networks to augment existing class advantages. Put differently, parental community ties do not appear to play a compensatory role for immigrants in the U.S., but instead facilitate social reproduction. Unfortunately, NELS data only allow us to speculate about what might cause these patterns. Perhaps, mainstream denominations (more likely to serve Caucasian families) provide access to gatekeepers, information, and valuable resources. Conversely, religious congregations serving Latinos (mostly Catholic) may have not provided the type of institutionalized resources that would help immigrant parents develop effective ties and access services or resources that might advance their children's academic placement odds. Future, perhaps qualitative-based, analyses are necessary to solve this puzzle.

We conclude that, in institutional contexts like the U.S., where the academic placement process is diffuse, parental networks (even presumably weak ties to institutional agents in the community) may help magnify ethnic differences in track placement, thus exacerbating inequalities in educational outcomes. Our findings also corroborate extant U.S. research showing that the most noticeable benefits of parental resources accrue to Caucasian children (Lareau and Horvat, 1999; McNeal, 1999; Royster, 2003).

We also find ethnic differences in how parental ties shape track placement odds in Germany. In this case, parental sports participation reduces the odds that ethnic Germans attend the vocational track placement, whereas similar involvement in sports and in ethno-religious organizations seems to boost non-Germans into the rigorous academic track. Given that many immigrants are of Turkish or southeastern European descent, it is unlikely that mainstream local Catholic and Lutheran congregations provide immigrant parents with ways to navigate the German educational system. Instead, alternative ethno-religious organizations most likely take their place (e.g., Christian Orthodox, Muslim). Again, data limitations do not permit us to examine the exact mechanisms creating these patterns. But our analyses illustrate that social institutions (secular and non-secular alike) that facilitate ties to non-school based gatekeepers or institutional agents can create compensatory po-

equal educational system, yet our analyses fail to find a negative immigrant effect once SES controls are included. Rather than suggesting that the German system is not ethnically and class-stratified, our results indicate that ethnic effects per se drop out in multivariate analyses precisely because of the strong class reproduction effects and the relative socio-economic homogeneity among immigrants in Germany. Thus, it is our understanding that findings from this study complement insights from PISA regarding Germany's strong class-ethnically based inequalities and social reproduction dynamics. We also note that PISA country rankings reflect domain-specific (reading, math, science) mean achievement scores. Though achievement differences within country are discussed in various PISA reports, the primary purpose of PISA data is not to document the distribution of students across tracks. Thus, apart from the fact that our outcome variable is more likely to gauge attainment rather than achievement, our analyses focus on the distribution (dispersion) of said outcomes, rather than on mean achievement (centrality). 
tential, in this case enabling immigrants to make up for lack of socio-economic resources. We argue that such ties are more likely to play a compensatory role in an institutional context dominated by a comparatively transparent track placement process, which facilitates otherwise pronounced, direct social reproduction effects. On a related note, it is also possible that immigrants in Germany are able to mobilize such resources more effectively on behalf of their children, an argument underscored by the fact that relatively small group differences in parental ties (Table 2) translate into powerful predictors in our multivariate analyses (Table 4). A more indepth exploration of this issue should be pursued in future studies.

Our study has several implications. First, as complex course-based assignment practices-including the addition of Advanced Placement and International Baccalaureate streams-become more pervasive in U. S. schools, the impact of non-SES based parental resources on educational outcomes is likely to become even more pronounced. If minimizing ethnic inequalities in educational outcomes remains a policy goal, innovative approaches are needed. Second, rather than stressing the importance of nuclear and extended family ties for long-term academic success, efforts might concentrate on fostering the development of community organizations as well as families' ability to gain access to them. Third, efforts to encourage community-based initiatives should recognize that ethnic majority and immigrant groups do not necessarily benefit from involvement in identical activities or organizations. In fact, it may be argued that traditional organizations at times have failed to address the needs of immigrant groups (as observed in the U.S.), and that alternative voluntary associations can fill that niche (as suggested in Germany). Future research and policy initiatives should focus on ways to facilitate the development of community organizations centered on immigrant families' needs, paying careful attention to how national context influences which social institutions and institutional agents play a role in the reproduction of inequalities. Looking towards traditional social service providers to meet these needs can lead to the erroneous conclusion that their importance has waned, just because entities that may have been key to the social fabric in a different institutional, temporal, or group context do not seem to play a role (Coleman, 1988; Offe and Fuchs, 2002; Putnam, 2000). Similarly, organizational venues superimposed by the ethnic majority are likely to create ineffective or counterproductive results.

In the introduction, we referred to our analysis as "explorative." Precisely because this comparative case study involves just two countries that epitomize drastically different modes of ability grouping, we call for additional research in this field. On the one hand, qualitative case studies might address the "black box" problem that prevents us from identifying the specific ways parental ties to community organizations shape track placement odds for different groups in different contexts. That is, we need to unravel the processes by which e.g. parental participation in religious or secular community organizations helps foster and activate resources that, in turn, influence track placement odds, as well as other outcomes related to long-term social mobility. On the other hand, we need additional quantitative studies that include a larger number of countries, to test more systematically our central contention that institutional context moderates ethnically specific social reproduction mechanisms. Such research can produce important insights for educational policy and public discourse, even if researchers have to compromise to some degree on using strictly identical measures and instead opt for functional equivalency to gauge how macro-level institutional parameters moderate micro-level family resource effects.

Acknowledgments - We are equal authors, listed in reverse alphabetical order. This research was supported by grants to the first author: a postdoctoral fellowship from the National Academy of Education/Spencer Foundation, the Spencer Foundation's Small Grants Program, and NSF grant \# SES-9986586. This material is partly based on work conducted while the first author served at the National Science Foundation. We thank our reviewers as well as Brian Powell for their feedback, Lauren Rauscher for her research assistance, and Martin Groeger, Radcliffe Quarterman, and Li-Ling Yang for their support. 


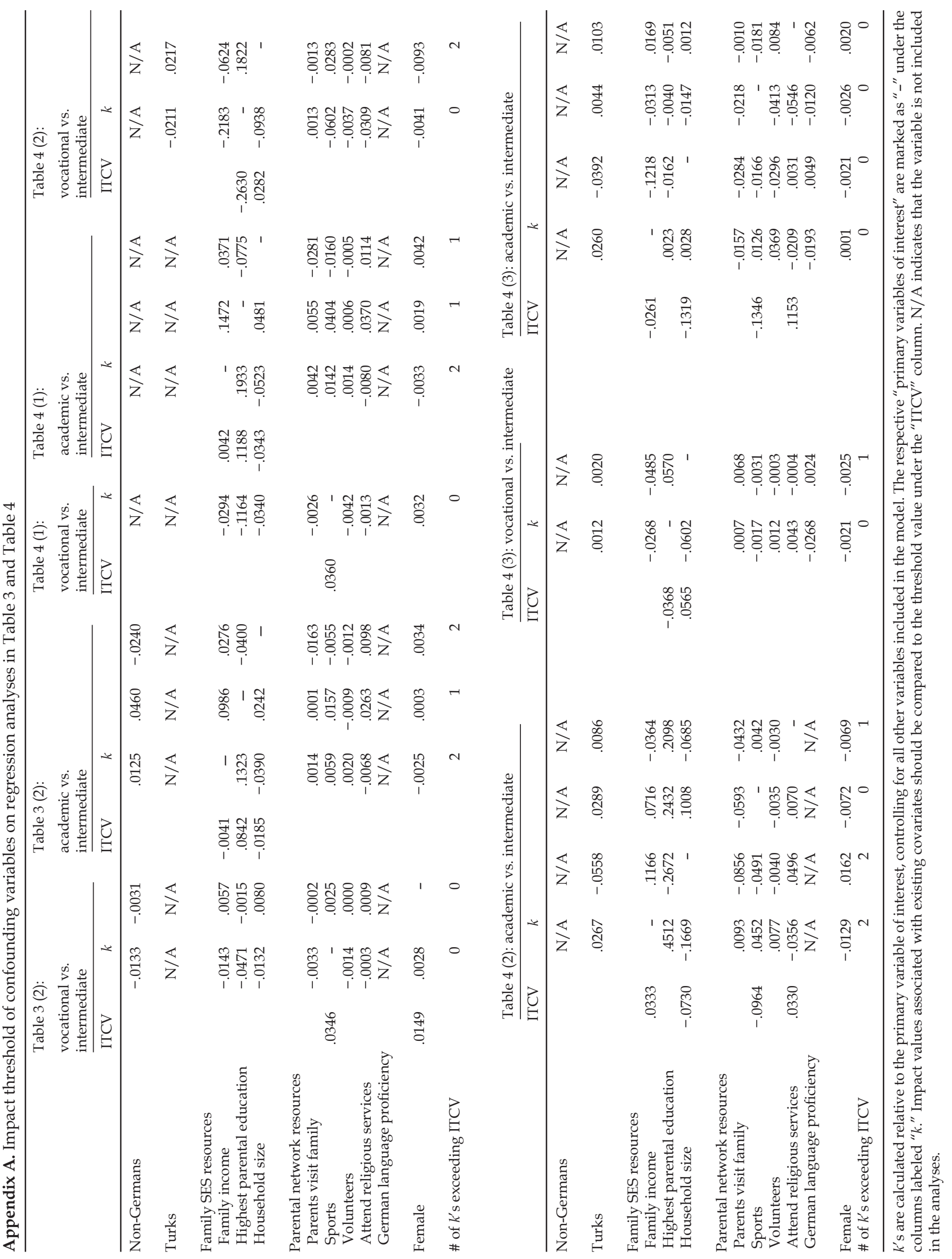




\section{References}

Aguirre, A., \& Martinez, R. (1984). Hispanics and the United States occupational structure: A focus on vocational education. International Journal of Sociology \& Social Policy, 4, 50-59.

Allmendinger, J. (1989). Educational systems and labor market outcomes. European Sociological Review, 5, 231-250.

Arum, R. (2000). Schools and communities: Ecological and institutional dimensions. Annual Review of Sociology, 26.

Arum, R., \& Shavit, Y. (1995). Secondary vocational education and the transition from school to work. Sociology of Education, 68, 187-204.

Ayalon, H., \& Gamoran, A. (2000). Stratification in academic secondary programs and educational inequality in Israel and the United States. Comparative Education Review, 44, 54-80.

Baker, D., Esmer, Y., Lenhardt, G., \& Meyer, J. (1985). Effects of immigrant workers on educational stratification in Germany. Sociology of Education, 58, 213-227.

Bankston, C. (2002). Social capital and immigrant children's achievement. Research in Sociology of Education, 13, 13-39.

Bankston, C. (2004). Social capital, cultural values, immigration, and academic achievement. Sociology of Education, 77, 172-175.

Baumert, J., Trautwein, U., \& Artelt, C. (2003). Schulumwelten: Institutionelle Bedingungen des Lehrens und Lernens. In J. Baumert, C. Artelt, E. Klieme, J. Neubrand, M. Prenzel, U. Schiefele, W. Schneider, K.-J. Tillmann, \& M. Weiß (Eds.), PISA 2000: Ein differenzierter Blick auf die Länder der Bundesrepublik Deutschland (pp. 261-331). Opladen: Leske + Budrich.

Bourdieu, P. (1977). Cultural reproduction and social reproduction. In J. Karabel, \& A. H. Halsey (Eds.), Power and ideology in education (pp. 487-511). New York: Oxford University Press.

Bourdieu, P. (1980). Le capital social: Notes provisoires. Actes de la Récherche en Sciences Sociales, 31, 2-3.

Bourdieu, P. (1986). The forms of capital. In J. G. Richardson (Ed.), Handbook of theory and research for the sociology of education (pp. 241-258). New York: Greenwood Press.

Breen, R., \& Jonsson, J. O. (2000). Analyzing educational careers: A multinomial transition model. American Sociological Review, 65, 754-772.

Brint, S., \& Karabel, J. (1989). The diverted dream: Community colleges and the promise of educational opportunity in America, 1900-1985. Oxford University Press.

Brooks, C., Nieuwbeerta, P., \& Manza, J. (2006). Cleavage-based voting behavior in cross-national perspective: Evidence from six postwar democracies. Social Science Research, 35, 88-128.

Brunello, G., \& Checchi, D. (2005). Family background and school quality in Italy. Economics of Education Review, 25, 563-577.

Büchel, F., \& Duncan, G. (1998). Do parents' social activities promote children's school attainments? Journal of Marriage and the Family, 60, 95-108.

Büchel, F., \& Wagner, G. (2000/2001). Der Einfluss elterlichen Sporttreibens auf die Bildungsbeteiligung ihrer Kinder. Zur empirischen Bedeutung eines wichtigen positiven externen Effekts des Sports. Sportwissenschaft, 30, 40-53.

Buchmann, C., \& Dalton, B. (2002). Interpersonal influences and educational aspirations in 12 countries. Sociology of Education, 75, 99-112.

Carbonaro, W. (1998). A little help from my friends' parents: Intergenerational closure and educational outcomes. Sociology of Education, 71, 295-313.

Cheng, S., Martin, L., \& Werum, R. E. (2007). Adult social capital: How family and community ties shape track placement of ethnic groups in Germany. American Journal of Education, 114, 41-74.
Cheng, S., \& Long, J. S. (2007). Testing for IIA in the multinomial logit model. Sociological Methods \& Research, 35, 583-600. Coleman, J. (1988). Social capital in the creation of human capital. American Journal of Sociology, 100, 1448-1478.

College Board. (2011). The history of the advanced placement program. Retrieved from http://apcentral.collegeboard.com/apc/public/ program/history/8019.html

DeGraaf, P. (1988). Parents' financial and cultural resources, grades, and transition to secondary school in the Federal Republic of Germany. European Sociological Review, 4, 209-221.

Dougherty, K. (1994). The contradictory college: The conflicting origins, impacts, and futures of the community college. Albany, NY: State University of New York Press.

Downey, D., \& Pribesh, S. (2004). When race matters: Teachers' evaluations of students' classroom behavior. Sociology of Education, 77, 267-282.

FOCUS Online. (2010). Integrationsbericht: Immer mehr Migrantenkinder ohne Schulabschluss. http://www.focus.de/politik/ deutschland/integrationsberichtimmer-mehrmigrantenkinderohneschulabschluss aid 527254.html

Frank, K. A. (2000). Impact of a confounding variable on a regression coefficient. Sociological Methods and Research, 292, 147-194.

Gamoran, A., \& Mare, R. (1989). Secondary school tracking and educational inequality: Compensation, reinforcement, or neutrality? American Journal of Sociology, 94, 1146-1183.

Garet, M., \& DeLany, B. (1988). Students, courses, and stratification. Sociology of Education, 61, 61-77.

Goodman, L. (1978). In J. Magidson (Ed.), Analyzing qualitative categorical data: Log-linear models and latent-structure analysis. Cambridge, MA: Abt Books.

Granovetter, M. S. (1983). The strength of weak ties: A network theory revisited. Sociological Theory, 1, 201-233.

Grant, L. (1998). Black Females' ‘Place’ in desegregated classrooms. Sociology of Education, 57, 98-111.

Haller, M. (1989). Klassenstrukturen und Mobilität in fortgeschrittenen Gesellschaften: Eine vergleichende Analyse der Bundesrepublik Deutschland, Österreichs, Frankreichs und der Vereinigten Staaten von Amerika. Frankfurt/New York: Campus.

Hallinan, M. (1992). Track mobility in secondary school. Social Forces, 74, 983-1002.

Henz, U. (1997). Der Beitrag von Schulformwechseln zur Offenheit des allgemeinbildenden Schulsystems. Zeitschrift für Soziologie, $26,52-69$.

Jungbauer-Gans, M. (2004). The influence of social and cultural capital on reading achievement. A comparison of Germany, France and Switzerland using PISA 2000 data. Zeitschrift fur Soziologie, 33, 375-397.

Kao, G. (2004). Social capital and its relevance to minority and immigrant populations. Sociology of Education, 77, 172-183.

Kao, G., \& Thompson, J. (2003). Racial and ethnic stratification in educational achievement and attainment. Annual Review of Sociology, 29, 417-442.

Karabel, J. (2005). The chosen: The hidden history of admission and exclusion at Harvard, Yale, and Princeton. Houghton Mifflin.

Kristen, C. (2002). Hauptschule, Realschule, oder Gymnasium? Ethnische Unterschiede am ersten Bildungsübergang. Kölner Zeitschrift für Soziologie und Sozialpsychologie, 54, 534-552.

Lareau, A. (1987). Social class differences in family-school relationships: The importance of cultural capital. Sociology of Education, 60, 73-85.

Lareau, A. (2002). Invisible inequality: Social class and childrearing in black families and white families. American Sociological Review, $67,747-776$. 
Lareau, A. (2003). Unequal childhood: Class, race, and family life. Berkeley: University of California Press.

Lareau, A., \& Horvat, E. M. (1999). Moments of social inclusion and exclusion: Race, class, and cultural capital in family-school relationship. Sociology of Education, 72, 37-53.

LeMay, M. (1987). From open door to Dutch door: An analysis of U.S. Immigration Policy since 1820. Westport, CT: Praeger.

Long, J. S. (1997). Regression Models for Categorical and Limited Dependent Variables. Thousand Oaks, CA: Sage Publications, Inc.

Long, J. S., \& Cheng, S. (2004). Regression models for categorical outcomes. In M. Hardy, \& A. Bryman (Eds.), Handbook of data analysis (pp. 259-284). Thousand Oaks, CA: Sage Publications.

Lucas, S. (1999). Tracking inequality: Stratification and mobility in American high schools. New York: Teachers College.

Lucas, S. R., \& Gamoran, A. (2002). Tracking and the achievement gap. In J. E. Chubb, \& T. Loveless (Eds.), Bridging the gap (pp. 171-198). Washington, DC: Brookings Institution Press.

Maurice, M., Sellier, F., \& Silvestre, J.-J. (1982). Politique d'Education et Organisation Industrielle en France et en Allemagne: Essai d 'Analyse Societal. Paris: Presses Universitaires de France.

McNeal, R. B., Jr. (1999). Parental involvement as social capital: Differential effectiveness on science achievement, truancy, and dropping out. Social Forces, 78, 117-144.

NCES. (1994). Curricular differentiation in public high schools. U.S. Department of Education, Office of Educational Research and Improvement.

NCES. (2010). Digest of education statistics 2009. http:// www.eric. ed.gov/PDFS/ED509883.pdf

Oakes, J. (1985). Keeping track: How schools structure inequality. New Haven, CT: Yale University Press.

Offe, C., \& Fuchs, S. (2002). A decline of social capital? The German case. In R. Putnam (Ed.), Democracies in flux (pp. 189-243). Oxford: Oxford University Press.

Oswald, H., Baker, D., \& Stevenson, D. (1988). School charter and parental management in West Germany. Sociology of Education, 61, 255-265.

Phalet, K., \& Schonpflug, U. (2001). Intergenerational transmission in Turkish immigrant families. Journal of Comparative Family Studies, 32, 489-504.

Portes, A., \& MacLeod, D. (1996). Educational progress of children of immigrants: The roles of class, ethnicity and school context. Sociology of Education, 69, 255-275.

Powell, B., \& Steelman, L. C. (1989). The liability of having brothers: Paying for college and the sex composition of the family. Sociology of Education, 62, 134-147.

Powell, B., Werum, R., \& Steelman, L. (2004). Macro causes, micro effects: Linking public policy, family structure, and educational outcomes. In D. Conley (Ed.), After the bell: Family background and educational success (pp. 111-144). London/New York: Routledge.

Putnam, R. (2000). Bowling alone: The collapse and revival of American community. New York: Simon and Schuster.

Ramirez, F., \& Boli, J. (1987). The political construction of mass schooling: European origins and worldwide institutionalization. Sociology of Education, 60, 2-17.

Rosenbaum, J. (2004). Beyond college for all: Career paths for the forgotten half. New York: Russell Sage Foundation.

Royster, D. (2003). Race and the invisible hand: How white networks exclude black men from blue-collar jobs. Berkeley, CA: University of California Press.
Rumberger, R. W., \& Larson, K. A. (1998). Toward explaining differences in educational achievement among Mexican American language-minority students. Sociology of Education, 71, 68-92.

Seifert, W. (1997). Occupational and economic mobility and social integration of Mediterranean Migrants in Germany. European Journal of Population, 13, 1-16.

Semyonov, M., \& Herring, C. (2007). Segregated jobs or ethnic niches? The impact of racialized employment on earnings inequality. Research in Social Stratification and Mobility, 25, 245-257.

Shavit, Y., \& Pierce, J. (1991). Sibship size and educational attainment in nuclear and extended families: Arabs and Jews in Israel. American Sociological Review, 56, 321-330.

Shavit, Y., \& Müller, W. (1998). From school to work: A comparative study of educational qualifications and occupational destinations. Oxford: Clarendon Press.

Stanton-Salazar, R., \& Dornbusch, S. (1995). Social capital and the reproduction of inequality: Information networks among Mexicanorigin high school students. Sociology of Education, 68, 116-135.

Stanton-Salazar, R., \& Spina, S. (2003). Informal mentors and role models in the lives of Urban Mexican-origin adolescents. Anthropology and Education Quarterly, 34, 231-254.

Teachman, J., Paasch, K., \& Carver, K. (1997). Social Capital and the generation of human capital. Social Forces, 75, 1343-1359.

Tönnies, F. (1922). Gemeinschaft und Gesellschaft. Berlin.

Vega, W. (1990). Hispanic families in the 1980s: A decade of research. Journal of Marriage and the Family, 52, 1015-1024.

Waldinger, R., \& Feliciano, C. (2004). Will the new second generation experience 'Downward Assimilation'? Segmented assimilation reassessed. Ethnic and Racial Studies, 27, 376-402.

Warren, J. R. (1996). Educational inequality among white and Mexican-origin adolescents in the American Southwest: 1990. Sociology of Education, 69, 142-158.

Weber, M. (1956). Wirtschaft und Gesellschaft. Tübingen.

Wuthnow, R. (2002). Religious involvement and status-bridging social capital. Journal for the Scientific Study of Religion, 41, 669-684.

$$
\circ \circ \circ \circ \circ
$$

Regina Werum was on leave in 2011 from her appointment as Associate Professor of Sociology at Emory University in Atlanta to serve as Program Director, Sociology, at the National Science Foundation. Since 2012 she has been at the University of Nebraska-Lincoln. Her academic interests include social stratification and educational policy, with comparative-historical and -international research designs. In addition to this ongoing venture, she has recently begun a project on the evolution of state-level homeschooling policies in the US since the 1970s.

Tomeka Davis is Assistant Professor of Sociology at Georgia State University in Atlanta. Her primary areas of interests include race, stratification, and the sociology of education. Her current research focuses on school choice and racial and class conflicts over schooling.

Simon Cheng is Associate Professor of Sociology at the University of Connecticut. His academic interests include race/ethnicity, education, family, and quantitative methods. His most recent publication focuses on the empirical questions of whether and how self-identified multiracial adolescents may differ from monoracial adolescents in psychological, social, and behavioral/educational outcomes 